International Journal of Child, Youth and Family Studies (2011) 3 \& 4: 510-526

\title{
HUMAN RIGHTS AND HEALTH PROMOTION: A CANADA FIT FOR CHILDREN?
}

\author{
Richard C. Mitchell
}

\begin{abstract}
The 2011 Canadian election campaign demonstrates once again that while the health care debate is always a highly contested political issue, little of the discussion originates from, or is concerned with, citizens under 18 years of age. This paper responds to this gap in knowledge with findings from a qualitative, exploratory human rights study investigating the youth-led health promotion group REACT (Resist, Expose and Challenge [big] Tobacco). Under the auspices of the Chief Medical Officer, successive cohorts of high-school students have been working within the Niagara Public Health Region in Ontario, Canada since 2005. The main findings suggest that young people are fully competent to manage important aspects of their own health, and have led authorities to support health-enhancing behaviours for themselves and their peers. Moreover, it is clear that rights-based health promotion has been underutilized in Canada since dominant theoretical approaches to healthy development and traditional top-down institutional processes frequently overlook - and thus violate - the participatory human rights of young people. This violation represents a social justice issue with far-reaching consequences for equity in the overall health of the Canadian population.
\end{abstract}

Keywords: human rights, determinants of population health, health promotion, sociology of childhood

Richard C. Mitchell, Ph.D. is an Associate Professor in the Department of Child and Youth Studies and Core Faculty of Brock Environmental Sustainability Research Unit at Brock University. Correspondence concerning this article should be addressed to Dr. Richard Mitchell, Department of Child and Youth Studies, Brock University, 500 Glenridge Avenue, St. Catharines, Ontario, Canada, L2S 3A1. Contact: rmitchell@brocku.ca 
International Journal of Child, Youth and Family Studies (2011) 3 \& 4: 510-526

The following study was undertaken with the assumption that new knowledge grounded within professional relationships is required to inform and reinvigorate the ongoing debate over children's rights in Canada (Human Resources and Skills Development Canada, 2004; Senate of Canada, 2007). It builds upon an earlier British Columbia investigation (Mitchell, 2000, 2003a, 2003b) that was similarly framed by the United Nations Convention on the Rights of the Child (United Nations, 1989; hereafter CRC). A second assumption builds on the work of the great 20th century Brazilian educator Paulo Freire, who argued that all pedagogical approaches are political by their very nature, and conversely, all politics are pedagogical. In Canada, this would necessarily include the politics and pedagogies of children's human rights.

Adopting a descriptive, exploratory approach and ethnographic methods, I analyzed how the principles and provisions of the CRC were being utilized in a southern Ontario health care region from 2007 to 2009. The data were interpreted from a research standpoint drawing upon the "sociology of childhood" as a conceptual framework (James \& Prout, 1997; Matthews, 2007; Mitchell, 2003a, 2003b, 2005), a standpoint shaped by two decades of front-line practice with young people, their families and caregivers in British Columbia child welfare, youth justice, education, and mental health settings (Mitchell, 1996, 2010; Moore \& Mitchell, 2008). This approach differs from much of the current Canadian and U.S. child rights literature, as well as traditional "age and stage developmental approaches" adopted by many authors attempting to understand the challenges of children's rights (see, for example, Howe \& Covell, 2001, 2005; Hertzman \& Weins, 1996; Peter et al., 2007; Matthews, 2007).

The main findings offer an overview of, (a) how a group of secondary school students employed as health promotion agents are demonstrating leadership in a hierarchically-oriented regional health care system, and (b) a challenge to key concepts relative to healthy human development, human rights, and health promotion.

Furthermore, I argue that these findings reveal the extent to which dominant theoretical and policy discourses - particularly those conceptualizing "adolescent development" and “youth engagement” - can comfortably embrace young people’s human rights when working within public health promotion, policy development, and practice settings.

\section{Re-Theorizing Human Rights}

In order to illuminate notions of power, ability, gender, sexual identity, poverty, and ethnicity embedded within transdisciplinary discourses of law, childhood, human rights, and healthy development, O’Byrne (2003) has theorized a "sociology of human rights". He has suggested that a lack of coherence in application of human rights across many cultures may result from the confusion over notions of "universality" (ontological assumptions), and efforts to obtain new "knowledge" of human rights (epistemological assumptions). Following on with this thinking, an examination of the roots of human rights in contemporary law and social policy reveals that many authors employ concepts that first emerged in the context of western European, Enlightenment-era debates to be subsequently codified after the French and American Revolutions (for example, 
Donnelly, 1993, 2003; Douzinas, 2000). These erroneous assumptions ignore the plethora of historical socio-political and cultural antecedents across many civilizations (Belden Fields, 2009; Ishay, 2004). The Cylinder of Cyrus (circa 539 BCE, but recently in the news upon its return from Iran to the British Museum), the Code of Hammurabi (circa 1790 BCE), and the Scottish Declaration of Arbroath (1320 CE) each offer evidence of historically and culturally situated efforts to articulate and implement political rights for oppressed populations. These predate the Enlightenment-era philosophies favoured by many Anglo-American human rights scholars. Indeed, while still engaged in the unfinished emancipatory march for women, indigenous people, children, racial and ethnic, physically and intellectually challenged, and/or sexual-identity minorities, western notions have thus far prevailed - although grassroots uprisings recently facilitated by social media in many middle eastern countries could turn these dominant assumptions even further aside (see Support Democracy for Egypt, 2011).

Canada enjoys an international reputation as a bastion of human rights compared to many nations (United Nations Development Program, 2011) - a reputation increasingly being called into question under both neo-liberal and neo-conservative federal regimes for many groups of young people and individuals (Blackstock, 2005; Canadian Bar Association, 2009; Senate of Canada, 2007; United Nations Committee on the Rights of the Child, 1995, 2003). The testimony of one young woman's life experience during a 2006 Senate Standing Committee hearing on Human Rights succinctly articulates these gaps:

The adoption of the Convention and its very existence seems to me, a bunch of words written on a piece of paper, a lot of them have not been implemented in my life, and I have not seen any evidence of those rights actually affecting me ... It is also interesting when you consider the idea that those people that have those rights have no idea that they even exist. Let me tell you a little bit about my life experiences. Racism is a huge part of my life and a part of everything I have achieved or been denied (Ms. Hawa Mire, Senate of Canada, 2007, pp. 197-198).

The Senate report cited above was aptly entitled, Children: The Silenced Citizens, and is the most comprehensive study conducted in Canada since the CRC was ratified two decades ago. Echoing repeated calls from the U.N. Committee on the Rights of the Child $(1995,2003)$, the Senate report makes four fundamental recommendations that - if heeded - could see a paradigm shift in child, youth and family-serving sectors throughout the nation:

- $\quad$ make the Convention part of Canada's national legislative regime;

- $\quad$ establish a National Children’s Commissioner;

- $\quad$ improve implementation of the Convention in all government departments; and

- $\quad$ inform youth and the public through education and regular reports.

In keeping with these recommendations, the Canadian Paediatric Society (2007), which represents the nation's 2,500 pediatricians, called for similar legislative reform in support of a federal Children's Advocate. In more than 60 countries, legislation creating these 
International Journal of Child, Youth and Family Studies (2011) 3 \& 4: 510-526

offices allows such advocates to function as de facto "Child and Youth Rights Commissioners” who operate at arms-length from partisan government interference. Indeed, after a lengthy period of debate and development, legislation introducing the "Independent Office of the Child Advocate" for New York State took place in late 2010, notwithstanding persistent U.S. federal government reluctance to ratify the CRC (New York State Senate, 2011). There is no similar draft legislation on the current federal agenda in Canada, thus ensuring that children and young people continue to be silenced within political and policy debates at time of this writing (see also Mitchell, 2000, 2005, 2010).

In a parallel discussion, we find that health and well-being have emerged in recent decades as a globally accepted "human rights" principle - a principle that drives the mandate of at least one academic journal, Harvard University's Health and Human Rights. In Canada's federally funded national health care system, traditional developmental models are embedded within the overarching policy framework known as "the determinants of population health" (Hertzman \& Weins, 1996; Mitchell, 2000, 2003a). Table 1 cross-references these determinants with corresponding CRC Articles and is reprinted with permission from the Canadian Journal of Public Health (Mitchell, 2003a, p. 415).

Table 1: Determinants of Population Health and the CRC

\begin{tabular}{|l|l|}
\hline $\begin{array}{l}\text { Income and social status - Described as the } \\
\text { single most important determinant of } \\
\text { health. }\end{array}$ & Articles 2-4, 6-8, 12-17 and 27. \\
\hline $\begin{array}{l}\text { Social supports and networks - Support } \\
\text { from families, friends and communities is } \\
\text { associated with better health. }\end{array}$ & Articles 2, 3, 6, 12-17 and 24-29. \\
\hline $\begin{array}{l}\text { Education - Health status improves with } \\
\text { the level of education. }\end{array}$ & Articles 24.2, 28, 29, 32-33, and 42. \\
\hline $\begin{array}{l}\text { Physical environments - Factors in the } \\
\text { natural environment (air and water quality) } \\
\text { are critical influences on health. The } \\
\text { human-built environment is also noted as } \\
\text { an important influence. }\end{array}$ & Articles 2, 6, 9, 19 and 32-37. \\
\hline $\begin{array}{l}\text { Biology and genetic endowment - } \\
\text { Individual genetic endowment and } \\
\text { functioning of various bodily systems are } \\
\text { fundamental determinants of health. }\end{array}$ & Articles 2, 3, 6 and 12. \\
\hline $\begin{array}{l}\text { Healthy child development - The effect of } \\
\text { prenatal and early childhood experiences } \\
\text { on subsequent health, well-being, coping } \\
\text { skills, and competence is powerful. }\end{array}$ & Articles 2, 3, 4, 6, 12, 13, 18, 19 and 23- \\
\hline
\end{tabular}


International Journal of Child, Youth and Family Studies (2011) 3 \& 4: 510-526

\begin{tabular}{|l|l|}
\hline $\begin{array}{l}\text { Health services - Maintenance and } \\
\text { promotion of health, prevention of } \\
\text { diseases, and restoration of health } \\
\text { contribute to healthy populations. }\end{array}$ & Articles 24, 25, 27 and 39. \\
\hline $\begin{array}{l}\text { Culture - Some people or groups face } \\
\text { additional health risks associated with a } \\
\text { socioeconomic environment which is } \\
\text { determined by more dominant cultural } \\
\begin{array}{l}\text { values contributing to conditions of } \\
\text { marginalization, stigmatization, loss or } \\
\text { devaluation of language, lack of access to } \\
\text { culturally appropriate health care services. }\end{array}\end{array}$ & $\begin{array}{l}\text { Articles 2-6, 8-15, 18-20, } \\
\text { 23-29, with emphasis on 30-31. }\end{array}$ \\
\hline $\begin{array}{l}\text { Employment and working conditions - } \\
\text { Those with more control over work } \\
\text { circumstances and fewer stress-related job } \\
\text { demands are healthier; unemployment is } \\
\text { associated with poorer health. }\end{array}$ & Articles 2-4, 6-8, 12-17, 24- \\
\hline $\begin{array}{l}\text { Personal health practices and coping skills } \\
\text { - Research in areas such as heart } \\
\text { disease/disadvantaged childhood shows } \\
\text { evidence that powerful biochemical and } \\
\text { physiological pathways link socioeconomic } \\
\text { experience to adverse health events. }\end{array}$ & $\begin{array}{l}\text { Articles 2, 3, 4, 6, 12, 13, 19 and 23-29, } \\
\text { and 39. }\end{array}$ \\
\hline
\end{tabular}

While the political portion of the Canadian health care debate is far removed from the lived experiences of most young people, the application of a common set of human rights principles adopted from the CRC offers a new framework for understanding their developmental capacities and taking them forward. The Convention still offers an innovative way to understand working relationships with young people in any professional context, and thus, the two theoretical frameworks in Table 1 - one top-down and health-oriented and the other top-down and legal - provide both a conceptual and a policy entry point for this investigation.

\section{Re-Theorizing Childhood}

In a seminal analysis of how various professionals are being educated in childhood studies, British early childhood educators Peter Moss and Pat Petrie (2002) argued that we have no "choice between 'theory' or 'no theory', or indeed between 'theory' and 'practice' ... Theories whether in the form of academic, political, or professional ideas ... shape our understandings and govern our actions, whether we recognize this or not ...” (p. 17). Indeed, they concluded that children's professionals, many of whom engage in the deficit labelling of the behaviourally "disordered", have thus far avoided this transformation (see also American Psychiatric Association, 2000). Moreover, they decried the present individualistic frameworks for children while highlighting an inclusive, holistic view of the changing conditions of children's existence 
across cultures and their potential contribution as competent, social actors: "We offer such examples ... more as lenses through which we may view ways of doing things and the assumptions that underpin them. We argue ... that working with different theories offers another set of lenses” (Moss \& Petrie, 2002, p. 10).

The CRC represents one such alternative theoretical view of young people, though repeated Canadian studies have found that little is known of the treaty at the elementary, secondary, or post-secondary educational levels or, for that matter, in professional and post-academic training (Howe \& Covell, 2001, 2005, 2007; Mitchell \& McCusker, 2008; Senate of Canada, 2007; see also United Nations Committee on the Rights of the Child 1995, 2003). Part of this omission may be attributed to pervasive notions within the child development and health care literature where young people are frequently misrepresented as "problems" to be solved, defined, and evaluated through conceptual lenses "of dysfunction, of deficit, and of deviance” (Roche, 1999, p. 477; Mitchell, 2003a, 2003b; Woodhead, 1999). From an American perspective, Matthews (2007) has considered how many U.S.-based childhood scholars "are on a somewhat different path than their colleagues in other Western countries” (p. 322). She noted that much of the impetus for this "new" sociology runs parallel with international CRC implementation, in that it has been ratified by all countries except the United States ${ }^{1}$. Like Woodhead (1999), she argued that young people are considered "not yet members of their societies" (Matthews, 2007) and identified three key ways in which theorists have begun to reshape universalized, linear thinking about how young people develop.

First, Matthews (2007, p. 324) noted how young people themselves are competent social actors impacting and shaping their own development as well as that of siblings, peers, and even adults in their lives. Secondly, strict developmental thinking "homogenizes children . . . regardless of social location or context" (Matthews, 2007, p. 325). Through this social constructionist view, she maintained that contemporary scholars in the interdisciplinary field of child and youth studies may "focus on how particular cultural representations of children [and youth] affect children's relationships, rights, and responsibilities” (Matthews, 2007). Finally, traditional thinking - at least over the past century - has focused on "the individual child” by divorcing his or her experiences from the social, political, and historical contexts within which they occur. Matthews has thus observed that "no matter how benign parents, teachers, and other adults may be, relationships between adults and children are characterized by differential power resources” (Matthews, 2007, p. 326; see also Karnieli-Miller, Strier, \& Pessach, 2009). Undoubtedly, the sociological view of childhood and its inherent assumptions of the competency of young people has detractors such as British legal theorist Michael King (1994, 2007), whose autopoietic analyses of the CRC have thus far failed to include viewpoints from young people themselves. Indeed, he has argued such human points-ofview are quite irrelevant to an appreciation of the CRC as a form of systemic legal communication.

\footnotetext{
${ }^{1}$ Notably, Matthews overlooked the case of Somalia, which also has declined ratification of the CRC due to political chaos.
} 
International Journal of Child, Youth and Family Studies (2011) 3 \& 4: 510-526

Returning to the Canadian context, a recent Senate report on population health policy has noted that some good practices with young people coexist in the country and may be found, for example, in the "Healthy Child Manitoba" initiative. Noting that even when well-integrated,

health care services alone do not make a community healthy. Governments at all levels should support an overall, community-based approach to health and human development and assist with the integration of health and social services, wherever possible, and where it makes sense for the users. (Senate of Canada, 2009, Introduction)

This integration runs headlong into the interplay of conflicted notions of health, wellbeing, and child development that, for many professionals, are founded upon exceedingly different concepts. As Scottish childhood researchers Hill and Tisdall (1997) have declared:

Rights, and the related concept of citizenship, constitute one of the most powerful discourses in today's world ... definitions of children's rights, and debates around them, are reliant on two concepts - of “childhood" and of "rights" - and how these two are combined. (p. 21)

In New Zealand, for example, Burrows and Wright (2007, p. 83) have considered how shaping health-enhancing attitudes of the young is "a weighty task" made more so by the sheer volume of perceived "risks" to their health in contemporary times. They further noted how alcohol, drug-taking, smoking, bullying, the sun, and "stranger danger" are just a few of the concerns dominating public and professional discourses the world over each running in parallel with and frequently contradicting the rights discourse. In a critical review of empirical studies on the competency of minors within U.K. health care, Alderson (2007) has noted problems of expanding "consent” beyond its current remit. She found that young people's changing status as rights-bearers and competent decisionmakers about health care "has gradually gained greater respect" (p. 2272). Also writing in Britain on the rights of young people, Coppock observed the over-prescription of stimulant medication and increased “medicalising” of young people's behavior (2002, p. 139) along with professional discourses (containing both written and assumed notions about "childhood" and "adolescence") informed decisions about what is "acceptable" and/or "appropriate" behavior. She concluded these judgments and the interventions upon which they were based had profound consequences in the lives of young people.

\section{Researcher Standpoint, Aims, and Methods}

This study's main goal has been to explore and report how successive groups of high school students have implemented the principles and provisions of the CRC, particularly the provision of health standards stated within Article 24.1, in their own and other organizations throughout the Niagara Region Public Health. This Article affirms that: "States parties recognize the right of the child to the highest attainable standard of health ... [and they] shall strive to ensure that no child is deprived of his or her right of 
International Journal of Child, Youth and Family Studies (2011) 3 \& 4: 510-526

access to such health care services”. In light of the plethora of power relations at work in the research context (Karnieli-Miller et al., 2009) and in order to articulate my own research standpoint, it is significant that for two decades I was a child and youth counsellor at various child psychiatry, education, social work, and youth justice sites in British Columbia. As such, I have researched and written about the Convention for more than 15 years (Mitchell, 1996, 2000, 2005) and have drawn not only upon feminist and participatory methodologies, but also Freirean critical pedagogy as theoretical and epistemological resources to inform and analyze these studies (Freire, 1970, 1999; Giroux, 2003; Smith, 1987, 1990).

As principal investigator, I worked alongside a research assistant during the initial phases of the study to deploy a descriptive, exploratory approach that utilized ethnographic methods over a 30-month period from 2007 to 2009. These methods included carrying out 15 participant observations, obtaining eight audiotaped person-toperson, open-ended key informant interviews and their transcription, and an in-depth series of legal, policy, and literature reviews. My relationship with Niagara Regional Chief Medical Officer, Dr. Robin Williams, was reflexive: It began in 2005 when I first approached her with the CRC and inquired how she and her senior managers might "engage" young people in health promotion using the treaty as a framework. As an innovative local health project, the organization of REACT was initially facilitated through the adoption of CRC principles (REACT, 2009; UNICEF Canada, 2007). With little empirical research available to guide public health officials in applying the Convention in Canada, Williams began recruiting cohorts of high school-aged activists and two adult mentors in 2005. They all received stipends for their assistance. "Resist Expose And Challenge [big] Tobacco" (REACT, 2009) was the result, and took shape as a peer-led, youth-driven, rights-based program that plans and implements initiatives throughout the regional education system with the intention of decreasing smoking rates among young people. Grounded theory procedures of open and axial coding and constant comparison of various forms of textual data with literature, policy, and observational data were employed (Glaser \& Strauss, 1967). The results of these comparisons with local and international observational data were further analyzed to facilitate identification of key findings.

\section{Results and Discussion}

The dataset included descriptions of the work of students participating in three different REACT cohorts as well as from adult mentors overseeing the program. The interviews and participant observations were conducted simultaneously with the United Nations mid-decade review of A World Fit for Children, the 2002 policy framework of commitments made by delegates from 180 countries to a global Action Plan supporting children's human rights. Five years later, the 2007 REACT group were active participants in the Canadian portion of this review entitled, A Canada Fit for Children in a World Fit for Children, a cross-national project led by UNICEF Canada with seed funding from the Department of Canadian Heritage (UNICEF Canada, 2007). 
As one of a dozen university-based collaborators in this coast-to-coast domestic review, in December, 2007 I was fortunate to attend U.N. General Assembly sessions to hear delegates review their own national Action Plans for Children, including those from Canada. These observations facilitated a deeper integration and grounded analysis of the "local" dataset within the "global" framework for understanding young people's human rights. The following findings illustrate this analysis and offer an overview of how a rights-based, population health approach to local heath promotion and youth activism unfolded. The first group observed the extent to which government coffers at various levels were being swelled by cigarette taxes, largely procured from underaged smokers who had been targeted to buy tobacco products through advertising in Canada and beyond. Declaring that "there are some things taxpayers should not buy. For Big Tobacco's debt let's make them pay”, the students produced the "Mighty Card" - a mock credit card to be presented to Ontario government officials with the group's request to access a portion of those taxes for youth-oriented benefits (Figure 1).

Figure 1 - The Mighty Card

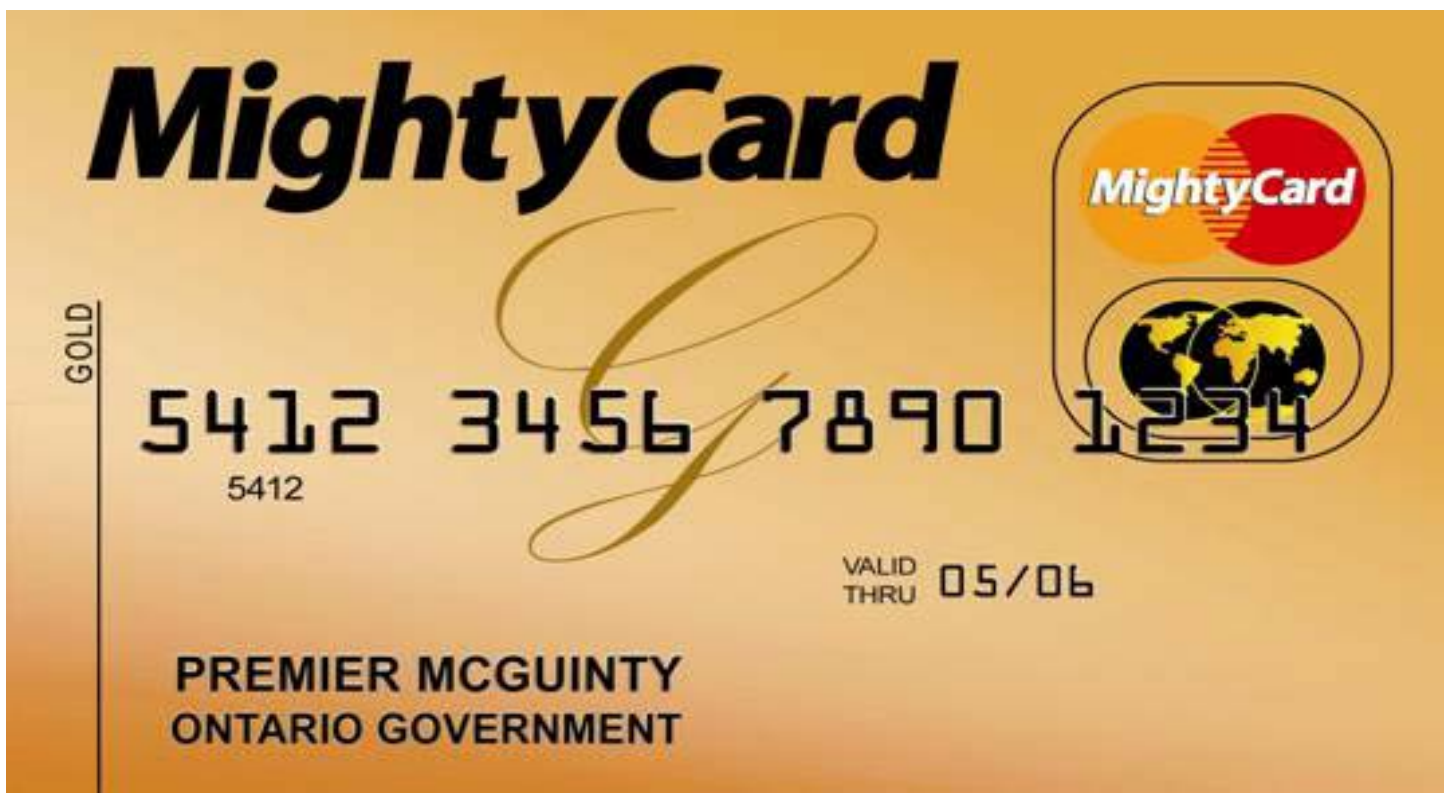

The 2007 REACT cohort also “discovered” that not only were Canadian tobacco companies exporting cigarettes to children as young as 10 years of age in developing nations like Ghana, but that they were further utilizing millions of dollars in domestic tax revenue as subsidies. At a time when contraband tobacco and its widespread underground distribution had spiked domestic addiction rates, the students then took their case to the federal Minister of Health in Ottawa to seek a way to restrict these networks. They framed their arguments as a violation of both international human rights law and agreements found in the policy framework, “A Canada Fit for Children” (Human Resources and Skills Development Canada, 2004, pp. 10, 25). 
International Journal of Child, Youth and Family Studies (2011) 3 \& 4: 510-526

Added to these efforts, the 2008 cohort spent many summer afternoons collecting 25,000 cigarette butts from places including my own university campus and elsewhere in the Niagara Region. Filling a number of manikins with this odious litter helped illustrate not only deleterious health impacts on a local scale, but that cigarettes represent one of the largest worldwide sources of environmental pollution for the current and foreseeable future. This example of environmental pollution was used again during presentations to 300 elementary students during the local review of "A Canada Fit for Children” (UNICEF Canada, 2007, pp. 4, 17). A participant in the cross-Canadian public initiative, Ms. Cara Bulger - a REACT peer leader for the three successive cohorts cited above offered an analysis of how the group brought the Convention into their work.

REACT's main goal is to prevent youth from ever starting to smoke [but] the fact that we are youth-based is what makes us unique ... There is a lot of peer pressure that youth face and providing another voice that reassures us that we can make our own decisions is vital. REACT has conducted numerous events in the community to expose the tobacco industry's infringement on children's rights around the world. REACT requests that the Canadian government uphold their signing and ratification of the Convention on the Rights of the Child and stand up for children’s rights. (UNICEF Canada, 2007, p. 17)

She further described a key initiative:

Last year one of our big events was the "Mighty Card”. We got signatures from students in the high schools around the region saying that they want the Canadian government to sue tobacco industries for healthcare costs directly related to smoking and tobacco. And to sign this as future taxpayers saying "we don't want any more of our money going into that. They should be paying for it”. (see also UNICEF Canada, 2007, p. 17)

Another participating student recalled:

I saw their sign and started reading "you'll work a maximum of six hours and get about ten dollars an hour”. So I've been working since August of 2006 'til now [2007] and I'll be applying again next year. I think the fact that the health department has actually given youth the opportunity for a job [is how they have adopted the Convention].

I think that's it for sure because we've been given this opportunity to go out and speak to youth all around the region and in a way tell them about their rights, that they don't have to smoke, that the tobacco industry is manipulating them, and that they have a right not to fall under their nasty spell.

We did a presentation to a grade eight health class and ... I felt it was a very cool experience because these youth look up to us in a way because we are three to four years older. I also think that was very cool that I have a right to, you know, 
International Journal of Child, Youth and Family Studies (2011) 3 \& 4: 510-526

go into this classroom and tell them the information [Article 17] I knew and how I was trying to make a difference.

Another theme articulated by the majority of REACT peer leaders, as well as by their adult mentors, was the extent to which they felt young people in the group managed their own planning and programming. A health promotion manager responsible for the regional tobacco control program, David Lorenzo, observed:

My role is to facilitate paid youth who work with the health department and to manage the program in a creative way which can be very exciting especially from the creative standpoint, the infusion of new ideas usually without boundaries because they haven't yet been jaded on policy, on making sure things have to be done a certain way. We try to make it in a structure where it's not a top-down approach, more the bottom-up approach where it is truly youth-driven.

The youth deliver their findings, decide what part of the tobacco piece they want to talk about, and what they want to present to their peers. This is done with the youth being the leaders and the adult staff [act] more as facilitators and resources. They come in with great ideas and we just try to get out of the way.

The region's Chief Medical Officer, Robin Williams, responded to a question about whether the Convention's health provisions were being fully upheld in the Niagara Region:

Absolutely not! How can we make such a claim when one in five children is living here in poverty? What about obesity or the environment? The youth engagement model is now a permanent aspect of our Regional approach but what has surprised me most has been the resistance to this - the sense that this might cost more money or that someone could be sued, the litigious aspect of this rather than healthy developmental concerns. Another big "aha” for me has been hearing the voices of Aboriginal young people.

Finally, a key finding that was repeated by all younger key informants especially in light of the salience of the Convention as a set of organizing principles for "engaging" young people - was articulated by another informant when asked whether s/he had received enough information about human rights:

No, not at all. In grade ten we have a civics class and that touches base on it [the $\mathrm{CRC}$ ] somewhat. But I just learned about this at the beginning of the year because our bosses actually gave us the blue booklet, the Convention, and we read through it. I had no idea this was going on, and that we have these rights implemented. I mean other than what they gave us I had no idea. I went "Wow! Where has this been, and when was it formed?” And even for the teachers not to express this, but they might not know either 'cuz I mean, it's not publicized. 
International Journal of Child, Youth and Family Studies (2011) 3 \& 4: 510-526

\section{Conclusions}

Analyses from international and Canadian legal and policy documents, comparative theory within the sociology of childhood and population health literature, findings elicited from participant observations in Ontario and during a United Nations global review, and a series of interviews conducted within the Niagara Region Public Health authority have been presented as part of an exploratory study of REACT, a health promotion group employed in southern Ontario, Canada. Rather than relying upon traditional notions of human development, deficit-labelling and deterministic beliefs about the lack of agency in young people, a holistic, rights-based approach was adopted in this study - one that assumes young people are competent social actors at any age. Results were analyzed utilizing a constant comparative technique and open and axial coding of texts first articulated by grounded theorists Glaser and Strauss (1967). The study found that using the CRC as a parallel to other youth engagement strategies is a practical and readily available theoretical, legal, and policy framework that could guide public health promotion and health-enhancing professional interventions.

As Alderson (2007), Coppock (2002), Lee (2001), Matthews (2007), Mitchell (2003a, 2003b), Scraton (1997), and Woodhead (1999, 2000) have all noted, historical notions of the competency of young people are being challenged by a gradual reconstruction of adult power relations within the context of articulating human rights relations in professional settings. This is particularly the case when an increased understanding of young people's capacity is allowed to play a role in "therapeutic research” (Alderson, 2007, p. 2273). Echoing this sentiment, I would propose that Alderson's study be used as a template for responding to any number of health promotion - and particularly environmental - concerns. Ultimately, the main problem with the Convention in Canada and elsewhere is a systemic resistance to the application of new knowledge in professional settings "engaged” with children: Politically, this has been seen in terms of a general lack of will and, ideologically, in terms of seeing young people as research and legal objects rather than subjects and co-constructors of knowledge.

Notwithstanding, it must be observed that a collective, wholesale disenfranchisement of young people has taken place in Canada - a disengagement that is further reflected and reinforced in the choice of young adults to opt out of the federal electoral processes en masse. This is disheartening to me as an educator and as a public intellectual. While it is well documented that youth engagement outcomes have tremendous societal and interpersonal benefits (Centres of Excellence for Youth Engagement, 2009), framing these research and policy initiatives within the framework of international law as rights-based has not occurred.

This study concludes with two questions that were posed to me by participants from two previous studies:

- "What kind of country gives its citizens rights but is afraid to tell them?"

- “Is Canada fit for children?” (Mitchell, 2010).

I would argue the latter question will remain unanswered until the former is addressed. 
International Journal of Child, Youth and Family Studies (2011) 3 \& 4: 510-526

\section{References}

Alderson, P. (2007). Competent children: Minors’ consent to health care treatment and research. Social Science and Medicine, 65, 2272-2283.

American Psychiatric Association. (2000). Diagnostic and statistical manual of mental disorders (4th Rev. ed.). Washington: Author.

Belden Fields, A. (2009). Human rights theory - Criteria, boundaries, and complexities. International Review of Qualitative Research, 2, 407-418.

Blackstock, C. (2005). Same country: Same lands; 78 countries away. The First Peoples Child and Family Review, 2(1), 130-158.

Burrows, L., \& Wright, J. (2007). Prescribing practices: Shaping healthy children in schools. The International Journal of Children's Rights, 15(1), 83-98.

Canadian Bar Association. (2009). Canadian Bar Association calls on Ottawa to accept Omar Khadr ruling. Calgary Herald. Retrieved from http://www.cba.org/CBA/news/2009_Releases/2009-04-24_khadr.aspx

Canadian Paediatric Society. (2007). Are we doing enough? Montreal: Author. Retrieved from http://www.cps.ca/English/Advocacy/StatusReport.htm

Central West Youth Coalition. (2007, August 10). Local youth rally for the protection of young people's rights. Hamilton: City Council. Retrieved from http://www.myhamilton.ca/myhamilton/CityandGovernment/NewsandPublication s/NewsReleases/2007News/August/mediareleaseaugust10_2007.htm

Centres of Excellence for Youth Engagement. (2009). Retrieved from http://www.engagementcentre.ca/

Coppock, V. (2002). Medicalising children's behaviour. In B. Franklin (Ed.), The new handbook of children's rights - Comparative policy and practice (pp. 139-154). London: Routledge.

Cyrus Cylinder Returns to British Museum. (2011, April 18) Tehran Times. Retrieved from http://www.payvand.com/news/11/apr/1171.html

Donnelly, J. (1993). Universal human rights in theory and practice. Boulder, CO: Westview Press.

Donnelly, J. (2003). What are human rights? Washington, DC: U.S. Department of State International Information Programs. 
International Journal of Child, Youth and Family Studies (2011) 3 \& 4: 510-526

Douzinas, C. (2000). The end of human rights. Oxford: Hart Publishing Ltd.

Freire, P. (1970). Pedagogy of the oppressed. London: Penguin Books.

Freire, P. (1999). Education and community involvement. In M. Castells, R. Flecha, P. Freire, H. A. Giroux, D. Macedo, \& P. Willis (Eds.), Critical education in the new information age (pp. 83-92). Boston: Rowman \& Littlefield Publishers, Inc.

Giroux, H. A. (2003). The abandoned generation - Democracy beyond the culture of fear. New York: Palgrave Macmillan.

Glaser, B., \& Strauss, A. (1967). The discovery of grounded theory - Strategies for qualitative research. Chicago: Aldine.

Hertzman, C., \& Wiens, M. (1996). Child development and long-term outcomes: A population health perspective and summary of successful interventions. Social Science and Medicine, 43(7), 1083-1095.

Hill, M., \& Tisdall, K. (1997). Children and society. London: Addison Wesley Longman Limited.

Howe, R. B., \& Covell, K. (2001). The challenge of children's rights in Canada. Waterloo, ON: Wilfrid Laurier Press.

Howe, R. B., \& Covell, K. (2005). Empowering children - Children's rights education as a pathway to citizenship. Toronto: University of Toronto Press.

Howe, R. B., \& Covell, K. (2007). A question of commitment - Children's rights in Canada. Waterloo, ON: Wilfrid Laurier Press.

Human Resources and Skills Development Canada. (2004). A Canada fit for children. Ottawa: HRSDC. Retrieved from http://www.hrsdc.gc.ca/eng/cs/comm/sd/news/2004/040510.shtml

Ishay, M. (2004). History of human rights, from ancient times to the globalization era. Berkeley: University of California Press.

James, A., \& Prout, A. (1997). Constructing and reconstructing childhoodcontemporary issues in the sociological study of childhood. Hampshire, UK: Routledge/Falmer Press.

Karnieli-Miller, O., Strier, R., \& Pessach, L. (2009). Power relations in qualitative research. Qualitative Health Research, 19(2), 279-289. 
International Journal of Child, Youth and Family Studies (2011) 3 \& 4: 510-526

King, M. (1994). Children's rights as communication: Reflections on autopoietic theory and the United Nations Convention. Modern Law Review, 57(3), 385-401.

King, M. (2007). The sociology of childhood as scientific communication Observations from a social systems perspective. Childhood, 14(2), 193-213.

Lee, N. (2001). Childhood and society - Growing up in an age of uncertainty. Maidenhead, UK: Open University Press.

Matthews, S. (2007). A window on the "new” sociology” of childhood. Sociology Compass, 1(1), 322-334.

Mitchell, R. C. (1996). The United Nations convention on the rights of the child and Canadian implementation efforts for indigenous children and youth. Child and Family Social Work, 1(4), 243-254.

Mitchell, R. C. (2000). Implementing children's rights in British Columbia using the population health framework. The International Journal of Children's Rights, 8(4), 333-349.

Mitchell, R. C. (2003a). Canadian health care and child rights - What are the links? Canadian Journal of Public Health/Revue Canadienne de Santé Publique, 94(6), 414-416.

Mitchell, R. C. (2003b). Ideological reflections on the DSM-IV-R (or Pay no attention to that man behind the curtain, Dorothy!). Child and Youth Care Forum, 32(5), 281-298.

Mitchell, R. C. (2005). Postmodern reflections on the UNCRC: Towards utilising Article 42 as an international compliance indicator. The International Journal of Children’s Rights, 13(3), 315-331.

Mitchell, R. C. (2010). Who’s afraid now? Reconstructing Canadian citizenship education through transdisciplinarity. Review of Education, Pedagogy and Cultural Studies, 31(1), 37-65.

Mitchell, R. C., \& McCusker, S. (2008).Theorizing the UN convention on the rights of the child within Canadian post-secondary education: A grounded theory approach. The International Journal of Children's Rights, 16(2), 159-176.

Moore, S. A., \& Mitchell, R. C. (Eds.). (2008). Power, pedagogy and praxis: Social justice in the globalized classroom. Boston, Rotterdam and Taipei: Sense Publishers.

Moss, P., \& Petrie, P. (2002). From children's services to children's spaces - Public policy, children and childhood. London: Routledge/Falmer. 
International Journal of Child, Youth and Family Studies (2011) 3 \& 4: 510-526

New York State Senate. (2011). S1052-2011: Establishes the independent office of the child advocate. New York: Open Senate. Retrieved from http://open.nysenate.gov/legislation/bill/S1052-2011

O’Byrne, D. J. (2003). Human rights - An introduction. London: Pearson Education.

Peter, E., Spalding, K., Kenny, N., Conrad, P., McKeever, P., \& Macfarlane, A. (2007). Neither seen nor heard: Children and homecare policy in Canada. Social Science and Medicine, 64, 1624-1635.

REACT. (2009). Resist, Expose And Challenge [big] Tobacco. Thorold, ON: Niagara Region Public Health. Retrieved from http://www.smokex.com/local/niagara/index.shtml

Roche, J. (1999). Children: Rights, participation and citizenship. Childhood, 6(4), 475-493.

Scraton, P. (1997). “Childhood” in “crisis”? London: Routledge.

Senate of Canada. (2007). Children: The silenced citizens - Final report on effective implementation of Canada's international obligations with respect to the rights of children. Ottawa: Standing Senate Committee on Human Rights. Retrieved from http://www.parl.gc.ca/39/1/parlbus/commbus/senate/com-e/huma-e/rep-e/rep10apr07-e.htm

Senate of Canada. (2009). A healthy productive Canada: A determinant of health approach. Ottawa: Standing Senate Committee on Social Affairs, Science and Technology. Retrieved from http://www.parl.gc.ca/40/2/parlbus/commbus/senate/com-e/popu-e/rep-e/rephealth1jun09-e.pdf

Smith, D. E. (1987). The everyday world as problematic: A feminist sociology. Boston: Northeastern University Press.

Smith, D. E. (1990). The conceptual practices of power - A feminist sociology of knowledge. Boston: Northeastern University Press.

Support Democracy for Egypt. (2011). Facebook. Retrieved from http://www.facebook.com/pages/Support-Democracy-for-Egypt/185762344778530

UNICEF Canada. (2007). Halfway there: A Canada fit for children in a world fit for children. Toronto: UNICEF Canada / Department of Canadian Heritage. Retrieved from http://www.unicef.ca/portal/Secure/Community/502/WCM/HELP/take_action/Advocacy/ WFC/WFFCMagE\%20sandra\%20change.pdf

United Nations. (1989). Convention on the rights of the child. New York: UN General Assembly. 
International Journal of Child, Youth and Family Studies (2011) 3 \& 4: 510-526

United Nations Committee on the Rights of the Child. (1995). Concluding observations / comments: Canada. Geneva: Office of the United Nations Commissioner for Human Rights. Retrieved from

http://www.unhcr.org/refworld/publisher,CRC,CONCOBSERVATIONS,CAN,3ae6af5a14,0.html

United Nations Committee on the Rights of the Child. (2003). Concluding observations / comments: Canada. Geneva: Office of the United Nations Commissioner for Human Rights. Retrieved from

http://www.unhchr.ch/tbs/doc.nsf/(Symbol)/995a15056ca61d16c1256df000310995?Opendocume $\underline{\mathrm{nt}}$

United Nations Development Program. (2011). International human development indicators - Canada. New York: United Nations Human Development Report Office. Retrieved from

http://hdrstats.undp.org/en/countries/profiles/CAN.html

Woodhead, M. (1999). Reconstructing developmental psychology - Some first steps. Children \& Society, 13(1), 3-19.

Woodhead, M. (2000). Children's rights and children's development: Rethinking the paradigm. In E. Verhellen (Ed.), Understanding children's right - Collected papers presented at $5^{\text {th }}$ international interdisciplinary course on children's rights (pp. 113-127). Belgium: University of Ghent. 